\title{
ADVANCEMENT AND APPLICATIONS OF JAPANESE HIGH PERFORMANCE STEEL IN STRUCTURAL ENGINEERING
}

\author{
Ping Xiang ${ }^{1}$, Hanbin $\mathrm{Ge}^{2, *}$ and Liang-Jiu $\mathrm{Jia}^{3}$ \\ ${ }^{1}$ Assistant Professor, Department of Structural Engineering, Tongji University, Shanghai, 200092, China \\ ${ }_{2 *}$ Professor, Department of Civil Engineering, Meijo University, 1-501 Shiogamaguchi, Tempaku-ku, Nagoya, \\ 468-8502, Japan \\ ${ }^{3}$ Assistant Professor, Research Institute of Structural Engineering and Disaster Reduction, Tongji University, \\ Shanghai, 200092, China. (Former Post Doctoral Researcher, Advanced Research Center for Natural Disaster Risk \\ Reduction, Meijo Univ., 1-501 Shiogamaguchi, Tempaku-ku, Nagoya, 468-8502, Japan) \\ *(Corresponding author: E-mail: gehanbin@meijo-u.ac.jp)
}

Received: 14 January 2014; Revised: 12 October 2015; Accepted: 13 October 2015

\begin{abstract}
Applications of steel to building structures in Japan can date back to the first steel factory, Shueisha Printing Plant, constructed in 1894. History of steel bridges in Japan can trace back to the first steel bridge, Kurogane Bridge in Nagasaki, constructed in 1868 using wrought iron. As the developments of large-scale structures, new construction technologies and demanding structural performance, a variety of high performance steels (HPSs) have been developed. In this study, history of applications of HPSs to building and bridge structures in Japan is briefly reviewed. The characteristics of typical HPSs in both buildings and bridges are introduced, respectively, and their impacts on structural engineering are also discussed.
\end{abstract}

Keywords: Steel, high performance, toughness, welding, ductility, weathering, buildings, bridges

DOI:10.18057/IJASC.2016.12.3.3

\section{INTRODUCTION}

Constructions of large-scale and large-span structures in developed countries tend to decrease in recent decades, and structural scales of most projects are becoming smaller in countries such as Japan and America. As a rival of reinforced concrete structures, steel structures are confronting a more and more competitive situation. Partially motivated by this concern, a number of high performance steels (HPSs) have been proposed to reduce construction cost, and employed in both building and bridge structures. As progress of new design concepts, connection details, fabrication technologies and mechanics, various properties such as higher strength, ductility, weldability, toughness, weathering and fireproofing properties, are increasingly demanded in practice. For example, design concept based on whole life cycle cost (LCC) is gaining more attention in steel bridges [1], which not only considers initial construction cost, but also maintenance expenses. From the viewpoint of LCC, durability related characteristics, such as weathering and fracture-resistant properties, are becoming more important issues for structural steels.

Before discussion on HPS, its definition is distinguished in different countries. In the USA, HPS is defined as having an optimized balance of strength, weldability, toughness, ductility, corrosion resistance and formability, to achieve the best overall performance of structures while remaining cost-effective [2-4]. A series of HPSs, HPS50W, HPS70W and HPS100W, were developed for steel bridges [3], where the aforementioned material properties are all considered through new manufacturing technologies including developments in metallurgical, rolling and heat-treatment. On the other hand, HPS in Japan commonly represents steels that have one or several virtues in strength, ductility, fire-proofing, weathering, weldability, toughness, cold formability, connecting feasibility $[5,6]$, etc. Therefore, the definition of HPS in Japan is broader than that in the USA, and there are more steel grades for HPS in Japan. In this study, Japanese HPSs developed respectively 
for building and bridge structures are introduced in terms of specific properties, such as strength, toughness, weldability, connection feasibility, durability properties etc.

\section{HIGH PERFORMANCE STEELS IN BUILDING STRUCTURES}

\subsection{General Comments}

It is commonly acknowledged that performance of a high-rise building structure is governed by serviceability considerations such as inter-storey drift, which is mainly related with stiffness of a material, boundary conditions (connection stiffness), structural systems and loading conditions. As it is known that steel has a stable elastic modulus, currently it is still not possible to increase its value. It is thus considered not economical to increase strength of a structural steel for common structural systems. However, it is still promising to employ high strength steels in building structures when new structural systems are proposed [7].

In addition, most of past design specifications mainly focus on tensile strength properties, with some attention paid to ductility, fracture-resistant and weldability properties. The aforementioned properties were once deemed good enough to guarantee favorable performance for serviceability, capacities and ductility. However, recent strong earthquakes such as the 1994 Northridge earthquake $[8,9]$ and the 1995 Kobe earthquake $[10,11]$ shake this confident belief in steel welded moment resisting frames, especially for the connections details and fracture-resistant properties of the steels and welding materials. The catastrophic consequences of the earthquakes arouse an extensive research on fracture mechanisms of steel welded structures [12-18], and more attentions are paid to fracture-resistant and weldability properties of steels $[19,20]$. As the development of new structural systems, fireproofing properties, connecting feasibility and energy dissipation capacity become more and more important in practice.

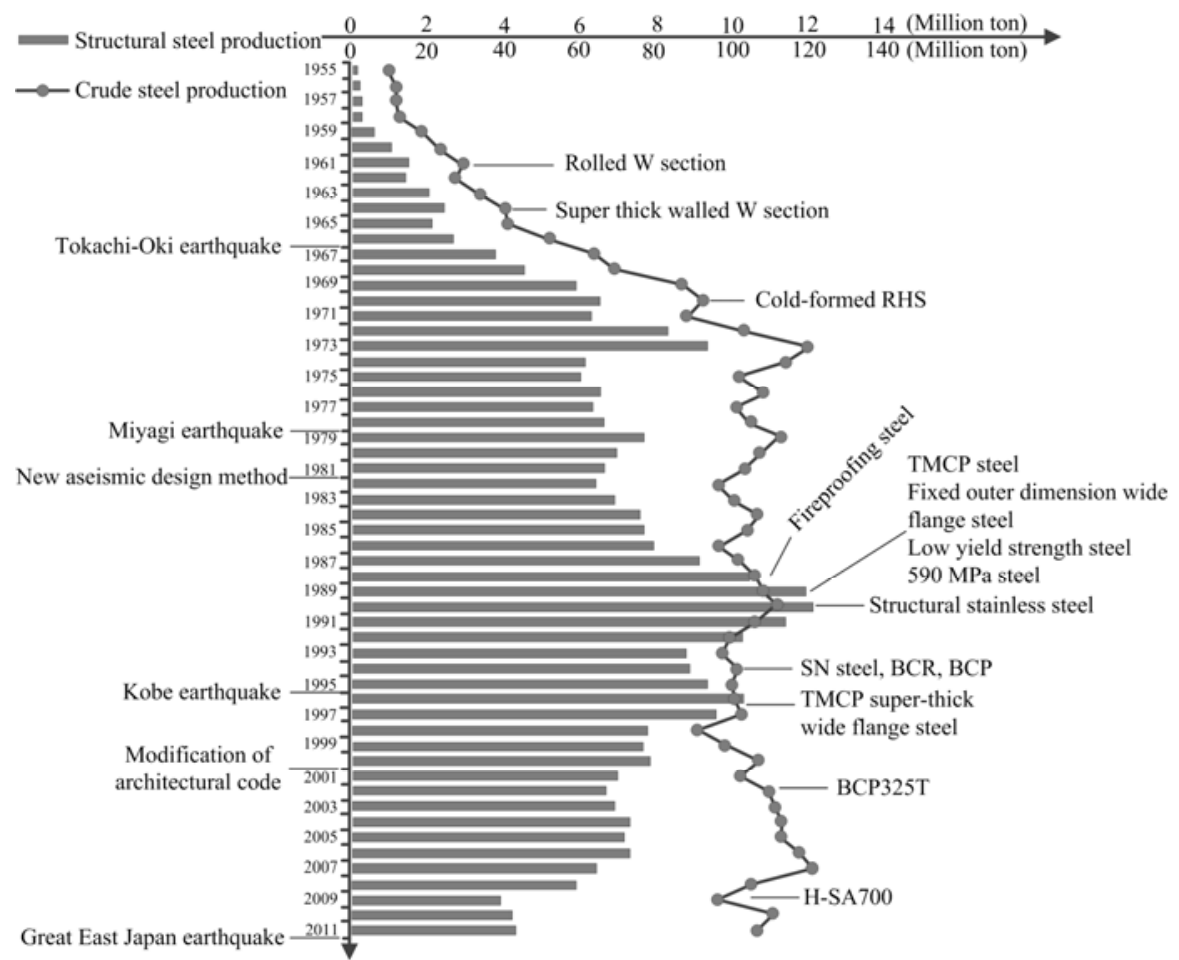

Figure 1. History of High Performance Steel in Building Structures (adapted from [21]) 
The Japanese crude steel and structural steel productions for building structures from the year of 1955 to 2011 are both plotted in Figure 1 [21], indicating that the structural steel production has passed its peak, while the crude steel production in recent forty years are quite stable. To promote application of steel structures, more economical structural systems, steels and corresponding manufacturing and connecting technologies are required. Strong earthquakes occurred in Japan are also marked in the figure, and a number of HPSs were developed as advancement in seismic design methods and steel manufacturing technologies etc.

\subsection{Strength Related HPSs}

\subsubsection{SN, BCR and BCP}

Before 1994, structural steels employed in buildings are SS (S: steel; S: structure) and SM (S: steel; M: Marine) series, which are also simultaneously employed in bridges and marine structures. Under the specific considerations of seismic design of building structures, deviations in the yield strength, tensile strength and yield-to-tensile strength ratio (YR) are of significant importance in the failure mechanisms of common frame structures [22]. To achieve better seismic performance and material weldability, a new series of HPS is developed for steel building structures in 1994, termed SN (S: steel; N: new) series [23]. Two corresponding series for cold formed rectangular hollow sections, BCR (box column-roll) and BCP (box column-press), are also developed, which have equivalent properties as those of the SN series. Mechanical and chemical properties of the SN steels are listed in Table 1. The SN steels has three types, A, B and C, and BCP steel has two types, B and C. For SN Types B and C, and BCR, BCP steels, the upper limit values for the yield strength is specified, and the YR has also to be less than 0.8 except for SN400A. These rules are proposed to ensure structures fail in an expected ductile mode as designed. The weldability is also considered by limiting the carbon content, equivalent carbon content, $C_{e q}$, carbon equivalent and composition parameter, $P_{c m} . C_{e q}$ is widely employed to evaluate weldability of a steel, while $P_{\mathrm{cm}}$ is generally employed in Japan. The two variables are respectively given in Eqns. 1 and 2,

$$
\begin{aligned}
& C_{e q}=C+\frac{S i}{24}+\frac{M n}{6}+\frac{N i}{40}+\frac{C r}{5}+\frac{M o}{4}+\frac{V}{14} \\
& P_{c m}=C+\frac{S i}{30}+\frac{M n}{20}+\frac{C u}{20}+\frac{N i}{60}+\frac{C r}{20}+\frac{M o}{15}+\frac{V}{10}+5 B
\end{aligned}
$$

\begin{tabular}{|c|c|c|c|c|c|c|c|c|c|c|c|c|c|c|}
\hline $\begin{array}{l}\text { Steel } \\
\text { grades }\end{array}$ & \multicolumn{5}{|c|}{ Yield strength (MPa) } & $\begin{array}{l}\text { Tensile } \\
\text { strength } \\
(\mathrm{MPa})\end{array}$ & \multicolumn{5}{|c|}{ Yield-to-tensile strength ratio } & \multicolumn{2}{|c|}{$\begin{array}{c}C_{e q} \\
\text { (Weight \%) }\end{array}$} & \multirow{2}{*}{$\begin{array}{l}\text { Charpy } \\
\text { impact } \\
\text { energy } \\
\text { at } 0^{\circ} \\
\text { (J) } \\
6<t \leq 100\end{array}$} \\
\hline $\begin{array}{c}\text { Thickness } \\
(\mathrm{mm})\end{array}$ & $6 \leq t \leq 12$ & $12 \leq t<16$ & 16 & $16<t \leq 40$ & $40<t \leq 100$ & & $6 \leq t \leq 12$ & $12 \leq t<16$ & 16 & $16<t \leq 40$ & $40<t \leq 100$ & $t \leq 40$ & $40<t \leq 100$ & \\
\hline SN400A & $\geq 235$ & $\geq 235$ & $\geq 235$ & $\geq 235$ & $\geq 215$ & \multirow{3}{*}{$400 \leq t \leq 510$} & - & - & - & - & - & - & - & - \\
\hline SN400B & $\geq 235$ & $235 \leq \sigma_{y} \leq 355$ & $235 \leq \sigma_{y} \leq 355$ & $235 \leq \sigma_{y} \leq 355$ & $215 \leq \sigma_{y} \leq 335$ & & - & $\leq 0.8$ & $\leq 0.8$ & $\leq 0.8$ & $\leq 0.8$ & \multirow[b]{2}{*}{$\leq 0.36$} & \multirow[b]{2}{*}{$\leq 0.36$} & \multirow{4}{*}{$\geq 27$} \\
\hline SN400C & $\begin{array}{c}\text { No } \\
\text { product }\end{array}$ & No product & $235<\sigma_{y}<355$ & $235<\sigma_{y}<355$ & $215<\sigma_{y}<335$ & & $\begin{array}{c}\text { No } \\
\text { product }\end{array}$ & $\begin{array}{c}\text { No } \\
\text { product }\end{array}$ & $\leq 0.8$ & $\leq 0.8$ & $\leq 0.8$ & & & \\
\hline SN490B & $\geq 325$ & $325 \leq \sigma_{y} \leq 445$ & $325 \leq \sigma_{y} \leq 445$ & $325 \leq \sigma_{y} \leq 445$ & $295 \leq \sigma_{y} \leq 415$ & \multirow[b]{2}{*}{$490 \leq t \leq 610$} & - & $\leq 0.8$ & $\leq 0.8$ & $\leq 0.8$ & $\leq 0.8$ & \multirow[b]{2}{*}{$\leq 0.44$} & \multirow[b]{2}{*}{$\leq 0.46$} & \\
\hline SN490C & $\begin{array}{c}\text { No } \\
\text { product }\end{array}$ & No product & $325 \leq \sigma_{y} \leq 445$ & $325 \leq \sigma_{y} \leq 445$ & $295 \leq \sigma_{y} \leq 415$ & & $\begin{array}{c}\text { No } \\
\text { product }\end{array}$ & $\begin{array}{c}\text { No } \\
\text { product }\end{array}$ & $\leq 0.8$ & $\leq 0.8$ & $\leq 0.8$ & & & \\
\hline
\end{tabular}

Table 1 Mechanical and Chemical Properties of SN Steels in Japan (JIS G 3136: 2012)

Charpy impact energy at $0^{\circ}$ is required to be no less than $27 \mathrm{~J}$ for SN Types B and C, BCR and $\mathrm{BCP}$ steels, to improve their fracture-resistant properties. In addition, thickness direction properties 
are also specified for Type C of SN and BCP steels. Applications of the SN, BCR and BCP steels in a welded steel frame (through diaphragm type) are shown in Figure 2 [21], where SN Type A steel is employed in secondary beams, SN Type B steel for beams and splice plates, SN Type C steel for diaphragms, BCR and BCP steels for columns. In Japan, the columns are commonly directly welded to the diaphragms, and the diaphragms are subjected to tensile stresses along the thickness direction under seismic loading. Thus, Type $\mathrm{C}$ steel is applied to the diaphragms.

\subsubsection{High strength steels}

High strength steels can reduce sectional size and thickness of structural members, which is correlated with reduced mass and gravity load. One of the main characteristics of high strength steels is a larger elastic domain compared with common mild steel. However, high strength steels are generally with a larger YR and a smaller elongation as illustrated in Figure 3, which are unfavorable for seismic design. For seismic design of structures, a small YR is favorable for a larger load-carrying capacity potential, and a large elongation is beneficial for its correlation with a large energy dissipation capacity. Therefore, application of high strength steels to seismic design of building structures is limited to only some structural components. On the other hand, a number of energy dissipation products have been proposed, and post-earthquake serviceability is paid more attention after the 1995 Kobe earthquake. A new design concept that main structural components such as beams and columns should remain elastic even during strong earthquakes receives more acknowledgements [7]. The seismic design concept for common steels and high strength ones are presented in Figure 4, where energy is dissipated through yielding of the beam and column ends for common steel frames, while through specific energy dissipation components for high strength steel frames. A research project aiming to develop a new damage-free structural system in intensity 7 earthquake (largest intensity in Japan) using super high strength steel has been carried out from the year of 2004 to 2008, e.g., [24-26]. To date, a number of super high strength steel grades, e.g., H-SA700 and BT-HT880, e.g., [27-29], have been proposed and recognized by the Japanese government. The mechanical and chemical properties of the high strength steels are listed in Table 2. It can be seen that the high strength steels have much larger $C_{e q}$ and YR than SN steels, indicating poor weldability and ductility properties of the materials. The YR can reach as large as 0.98 [30]. Meanwhile, the V-notched Charpy impact energy requirements are much higher than those for SN steels, indicating favorable fracture-resistant properties.

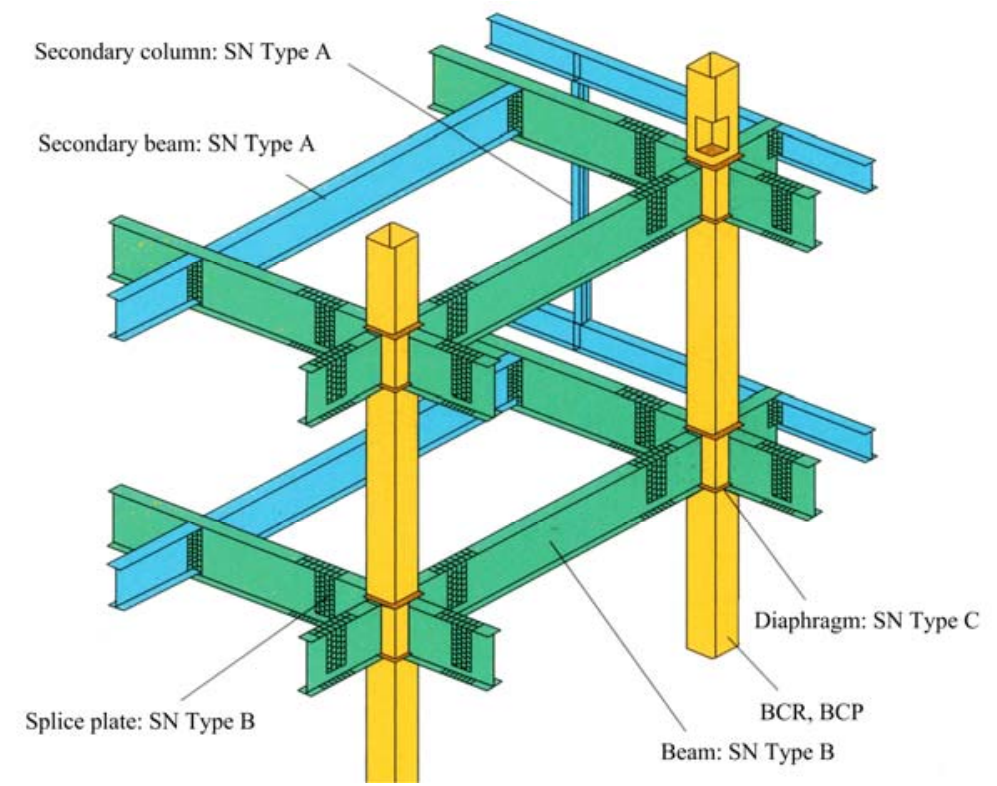

Figure 2 Application of SN and BCR, BCP Steels (adapted from [21]) 
Table 2 Steel Grades of High Strength Steels Qualified by Japanese Transportation Minister

\begin{tabular}{|c|c|c|c|c|c|c|c|c|c|c|}
\hline Shape & $\begin{array}{l}\text { Tensile } \\
\text { Strength }\end{array}$ & Company & Grade & \multicolumn{2}{|c|}{ Size } & $C_{e q}$ & $P_{c m}$ & Yield stress & YR & $\begin{array}{l}\text { Charpy } \\
\text { energy } \\
(\mathrm{J})\end{array}$ \\
\hline \multirow{11}{*}{ Steel plate } & \multirow{10}{*}{780} & \multirow{2}{*}{$\begin{array}{c}\text { Kobe } \\
\text { JFE } \\
\text { Nippon steel } \\
\end{array}$} & H-SA700A & \multirow{2}{*}{\multicolumn{2}{|c|}{$6 \leq t \leq 50$}} & $\leq 0.65$ & $\leq 0.32$ & - & $\leq 98$ & $\geq 47$ \\
\hline & & & H-SA700B & & & $\leq 0.60$ & $\leq 0.30$ & - & $\leq 98$ & $\geq 47$ \\
\hline & & \multirow{2}{*}{ Kobe } & KBSA630B & \multicolumn{2}{|c|}{$6 \leq t \leq 80$} & - & $\leq 0.30$ & 630 & $\leq 85$ & $\geq 47$ \\
\hline & & & KBSA630C & \multicolumn{2}{|c|}{$16 \leq t \leq 80$} & - & $\leq 0.30$ & 630 & $\leq 85$ & $\geq 47$ \\
\hline & & \multirow{4}{*}{ JFE } & JFE-HITEN780TB & \multirow{2}{*}{\multicolumn{2}{|c|}{$\begin{array}{l}22 \leq t \leq 100 \\
22<t<100\end{array}$}} & $\leq 0.60$ & $\leq 0.30$ & 630 & $\leq 85$ & $\geq 47$ \\
\hline & & & JFE-HITEN780TC & & & $\leq 0.60$ & $\leq 0.30$ & 630 & $\leq 85$ & $\geq 47$ \\
\hline & & & HBL630B-L & \multicolumn{2}{|c|}{$12 \leq t \leq 40$} & $\leq 0.60$ & $\leq 0.30$ & - & $\leq 85$ & $\geq 47$ \\
\hline & & & HBL630C-L & \multicolumn{2}{|c|}{$12 \leq t \leq 40$} & $\leq 0.60$ & $\leq 0.30$ & - & $\leq 85$ & $\geq 47$ \\
\hline & & \multirow{2}{*}{ Nippon steel } & BT-HT630B & \multicolumn{2}{|c|}{$9 \leq t \leq 100$} & $\leq 0.60$ & $\leq 0.30$ & 630 & $\leq 85$ & $\geq 47$ \\
\hline & & & BT-HT630C & \multicolumn{2}{|c|}{$9 \leq t \leq 100$} & $\leq 0.62$ & $\leq 0.30$ & 630 & $\leq 85$ & $\geq 47$ \\
\hline & 950 & Nippon steel & $\begin{array}{l}\text { BT-HT880B } \\
\text { BT-HT880C }\end{array}$ & \multicolumn{2}{|c|}{$9 \leq t \leq 50$} & $\leq 0.60$ & $\leq 0.34$ & 810 & $\leq 98$ & $\geq 70$ \\
\hline \multirow{3}{*}{ Pipe } & \multirow{3}{*}{780} & \multirow{2}{*}{ Nippon steel } & \multirow{2}{*}{ SA-TT630 } & \multirow{2}{*}{$\Phi 400 \sim 2200$} & $19 \leq t \leq 60$ & $\leq 0.60$ & $\leq 0.23$ & \multirow{2}{*}{780} & \multirow{2}{*}{$\leq 95$} & \multirow{2}{*}{$\geq 47$} \\
\hline & & & & & $60 \leq t \leq 80$ & $\leq 0.63$ & $\leq 0.28$ & & & \\
\hline & & Kobe & KAST630 & $\Phi 400 \sim 2500$ & $12 \leq t \leq 80$ & - & $\leq 0.30$ & 780 & $\leq 90$ & $\geq 47$ \\
\hline
\end{tabular}

Note: YR denotes yield-to-tensile strength ratio

To date, there are several applications of high strength steels to building structures. For example, concrete filled high strength steel columns $(780 \mathrm{MPa}$ steel) are employed in Obayashi Corporation's Technical Research Institute Main Building "Techno-Station" as illustrated in Figure 5 [31], where $160 \mathrm{MPa}$ high strength concrete is adopted. The slender columns have a superior architectural effect, and large span and space is realized by the application of the high strength steel. Amagasaki Research and Development Center shown in Figure 6 [32] is the first application of the $1000 \mathrm{MPa}$ high strength steel in the world, and the high strength steels are employed in columns of the first floor, where buckling restrained braces (BRBs) are also employed to absorb seismic energy during a strong earthquake. Sliding column bases and shear panels with the details shown in Figure 7 [32] are employed to prevent the beams and columns from yielding, and the beams and columns are designed to remain elastic even during a strong earthquake.

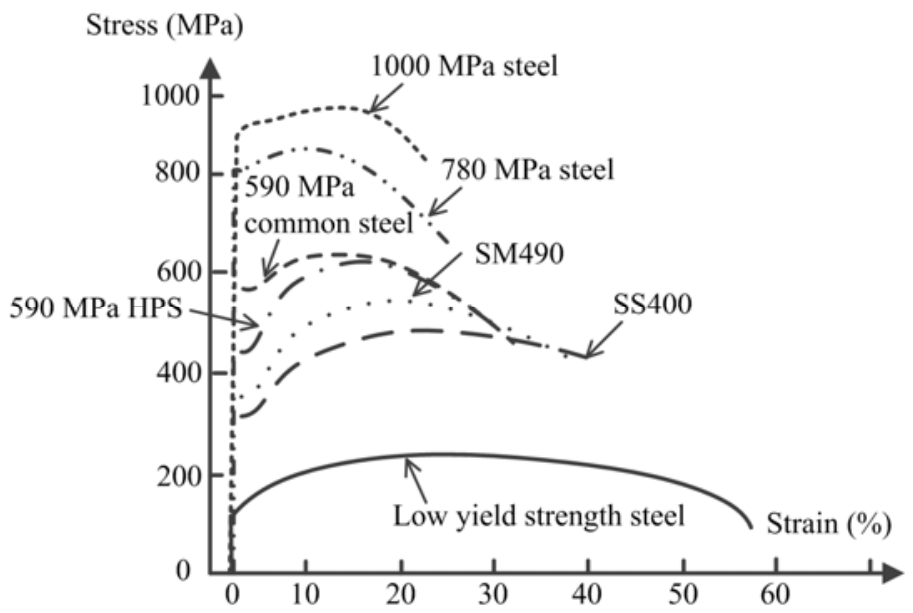

Figure 3. Stress-strain Curves of Common and High Performance Steels 


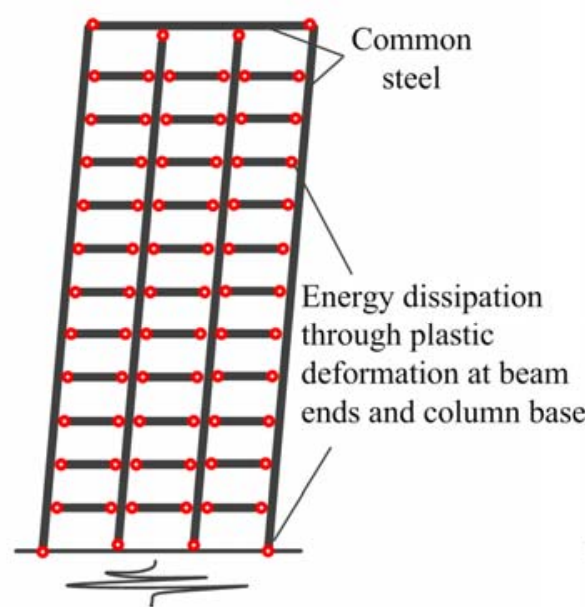

(a) Common steel frame

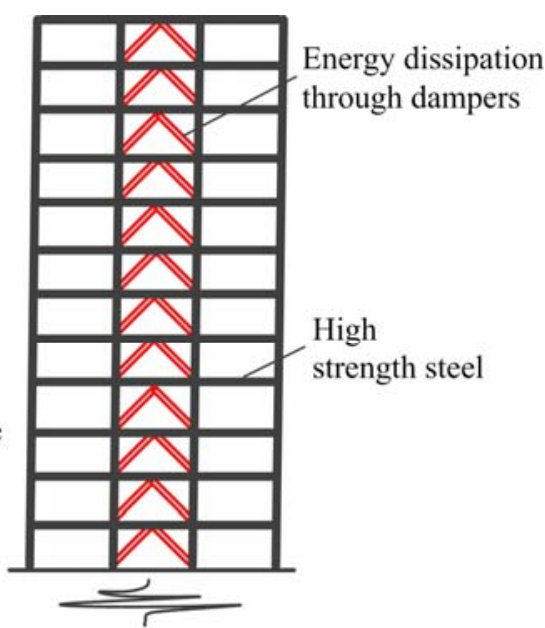

(b) High strength steel frame

Figure 4. Seismic Design Concept for Framed Structured Made of Common Steel and High Strength Steel

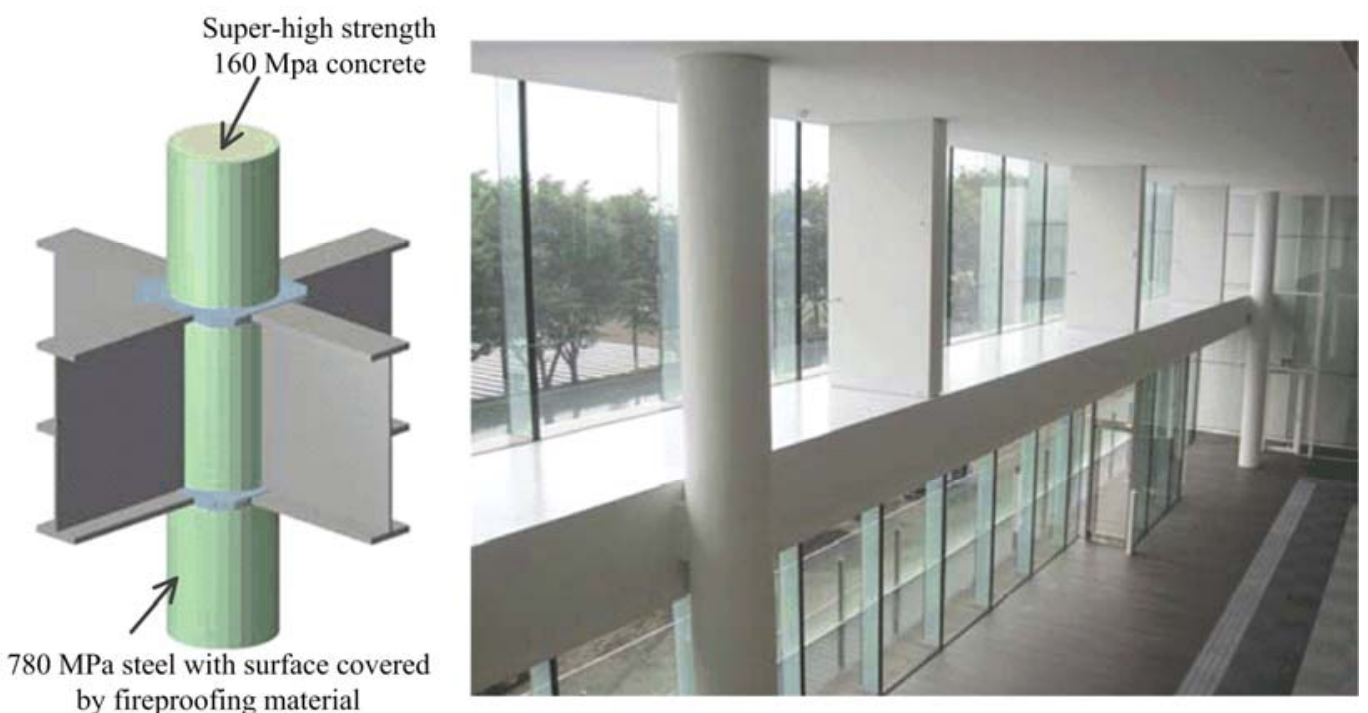

Figure 5. Application of $780 \mathrm{MPa}$ High Strength Steel (adapted from [31])

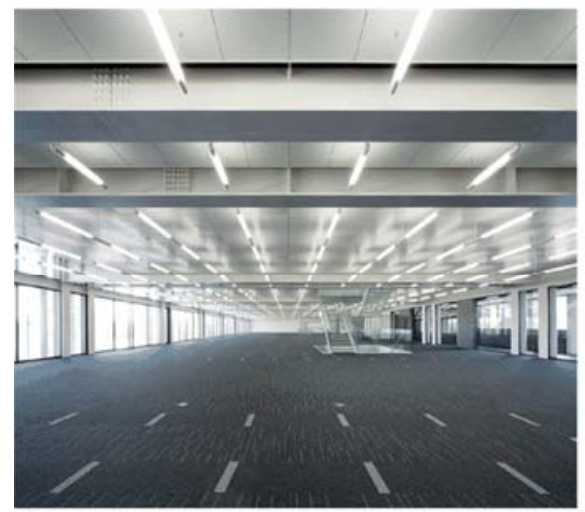

Large span and wide space

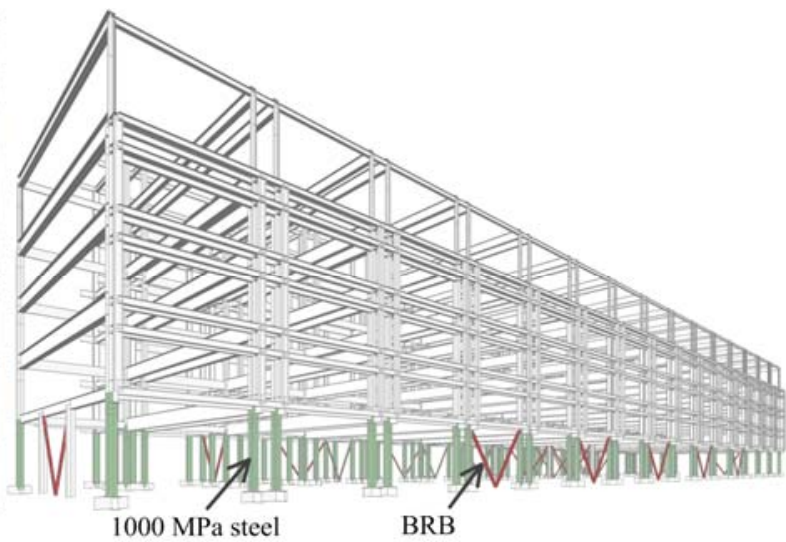

$1000 \mathrm{MPa}$ steel
BRB

Figure 6. Application of 1000 MPa High Strength Steel (adapted from [32]) 


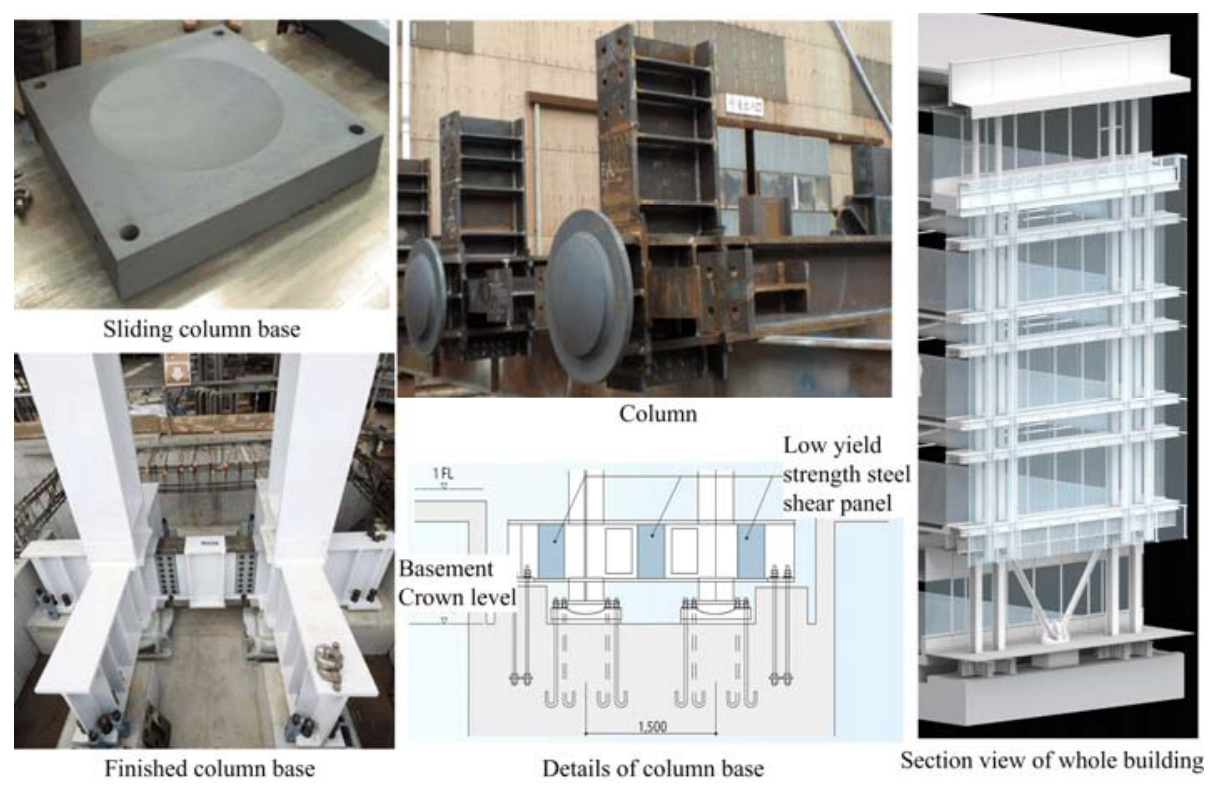

Figure 7. Details of Column Base in a Building Made of 1000 MPa High Strength Steel (adapted from [32])

\subsection{Ductility Related HPSs}

In recent several decades, a number of energy dissipation components, e.g., BRBs, oil dampers and shear fuses, have been developed and prevalently applied to seismic design of both building and bridge structures, where metallic dampers dissipating energy through plastic deforming of materials are a main category. Energy dissipation capacities of this type of dampers are mainly dependent on ductility of the material. A series of low-yield strength steels are developed aiming to improve the energy dissipation capacities of metallic dampers. In the year of 2000, low yield strength steels LY100 and LY225 for application to building structures were recognized by the Japanese government. The main characteristics of the two steels are:

(1) strict control for the yield strength ranges (LY100: 80-120 MPa; LY225: 200-245 MPa);

(2) high ductility in terms of elongation (LY100: $\geq 50 \%$; LY $225: \geq 40 \%$ ).

The ductility of the low strength steels is approximately twice of a common structural steel with an elongation of 20\%. Meanwhile, the YRs for LY100 and LY225 are also respectively restrained to be less than 0.6 and 0.8. Some dampers such as BRBs have relatively large load-carrying capacities, which may induce premature failure of the attached connections and frames. The low yield strength steels have a tensile capacity one third to half of common steels, which can thus greatly reduce the demanding load-carrying capacities of the attached structural components.

\subsection{Fireproofing HPS}

Fire resistant property is one of the main concerns in steel structures, and commonly fireproofing coating is required to prevent sudden loss of load-carrying capacity of steel structural components. However, it takes time and expense to carry out fireproofing coating, and it also impairs architectural values of structures. To overcome these deficiencies, fireproofing steel is developed to shorten construction period, enlarge effective architectural space and reduce costs of maintenance etc. The steel has equivalent mechanical properties with common structural steel under normal temperature, while lower decreasing rate of load-carrying capacity compared with common steel under high temperature as shown in Figure 8 [33]. The fireproofing steel SN490-FR under $600{ }^{\circ} \mathrm{C}$ 
can sustain more than two thirds of the yield strength under normal temperature. It has been employed in parking lots, atriums, external steel structures, art galleries, gyms etc., and an application to external steel structure is illustrated in Figure 9 [33].

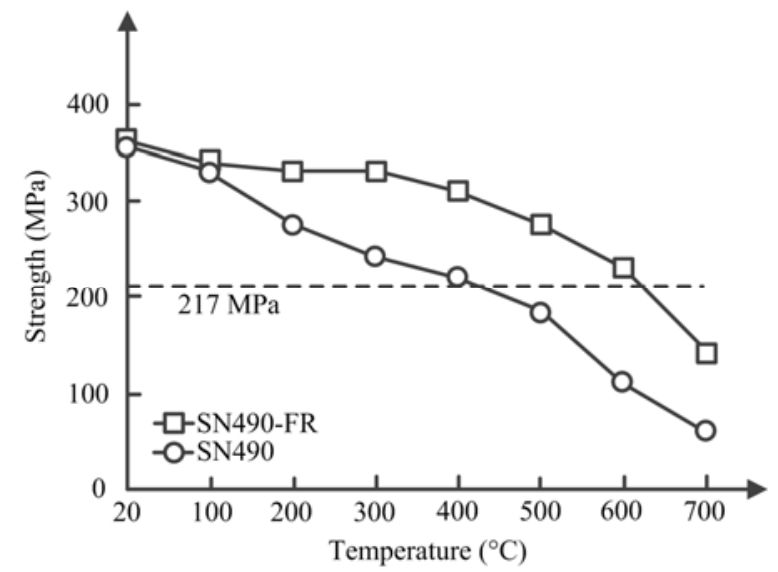

Figure 8. Comparison of Fireproofing Steel and Common Steel (adapted from [33])
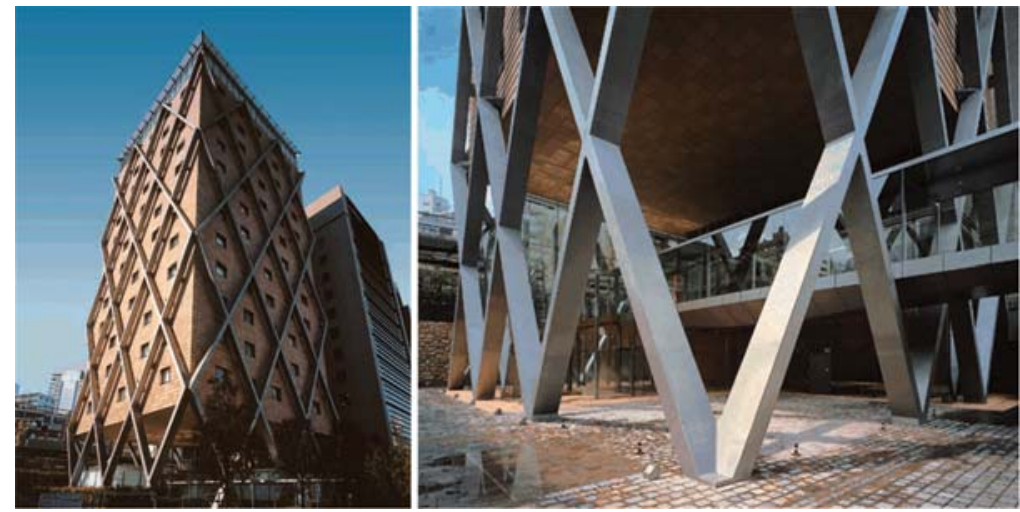

Figure 9. Application of Fireproofing Steel in a Building Structure (adapted from [33])

\section{HIGH PERFORMANCE STEELS IN BRIDGE STRUCTURES}

\subsection{General Comments}

Vehicle dynamic load make fatigue cracking a main issue in steel bridges, which is different from steel buildings. Meanwhile, steel bridges are frequently exposed to more corrosive environments, and this corrosion is significantly enhanced due to marine (salt spray) exposures especially in Japan. Another issue is that many aging bridges constructed over 50 years ago require maintenance or rehabilitation. Design concept based on LCC [1] is increasing popular in new constructed and rehabilitated steel bridges, along with the aforementioned characteristics make durability related properties of steel more demanding in bridge structures.

The application history of steel to bridges along with the revisions of specifications for highway bridges is presented in Figure 10 [6], which indicates that weathering steels have been employed for a long history since around the year of 1973. A significant progress in manufacturing technology is the thermo-mechanical control process (TMCP) initiating in 1980s. Fine microstructures produced using the controlled-rolling and controlled-cooling method as shown in Figure 11 [34] can greatly improve the strength and toughness properties of steel. Main 
advancement of HPSs in bridge structures occurred in 1990s, and a large variety of HPSs have been developed using the TMCP technology and employed in practice based on the revised specification.

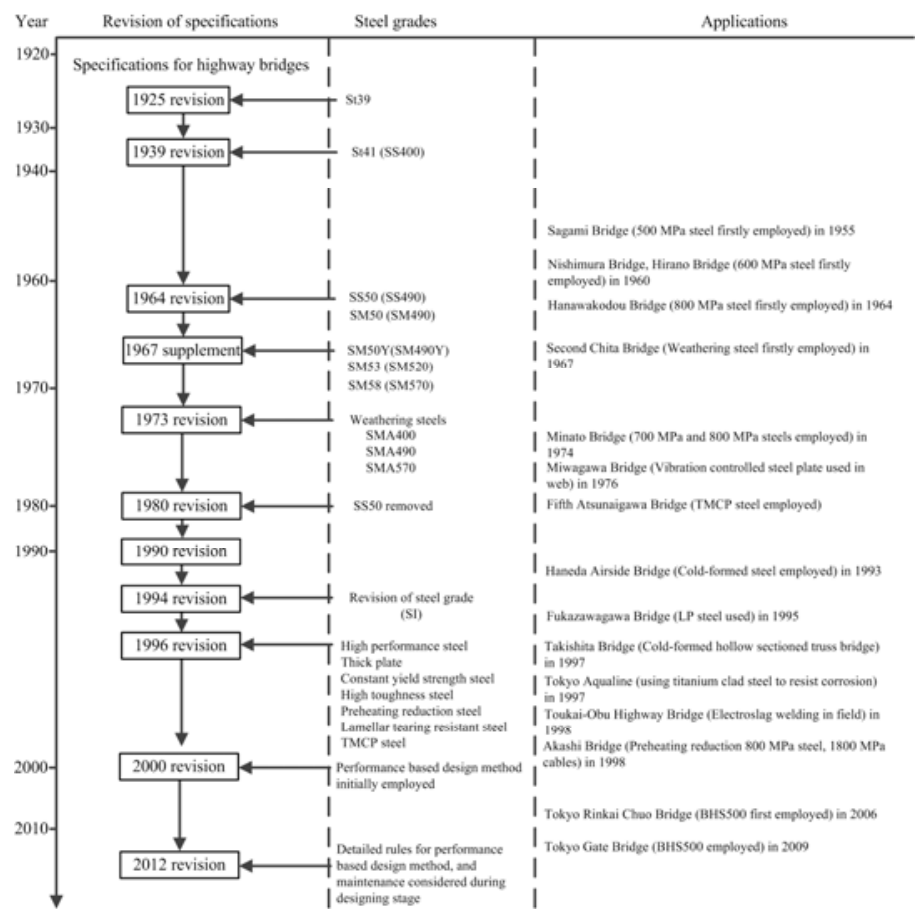

Figure 10. History of High Performance Steel in Steel Bridges (adapted from [6])

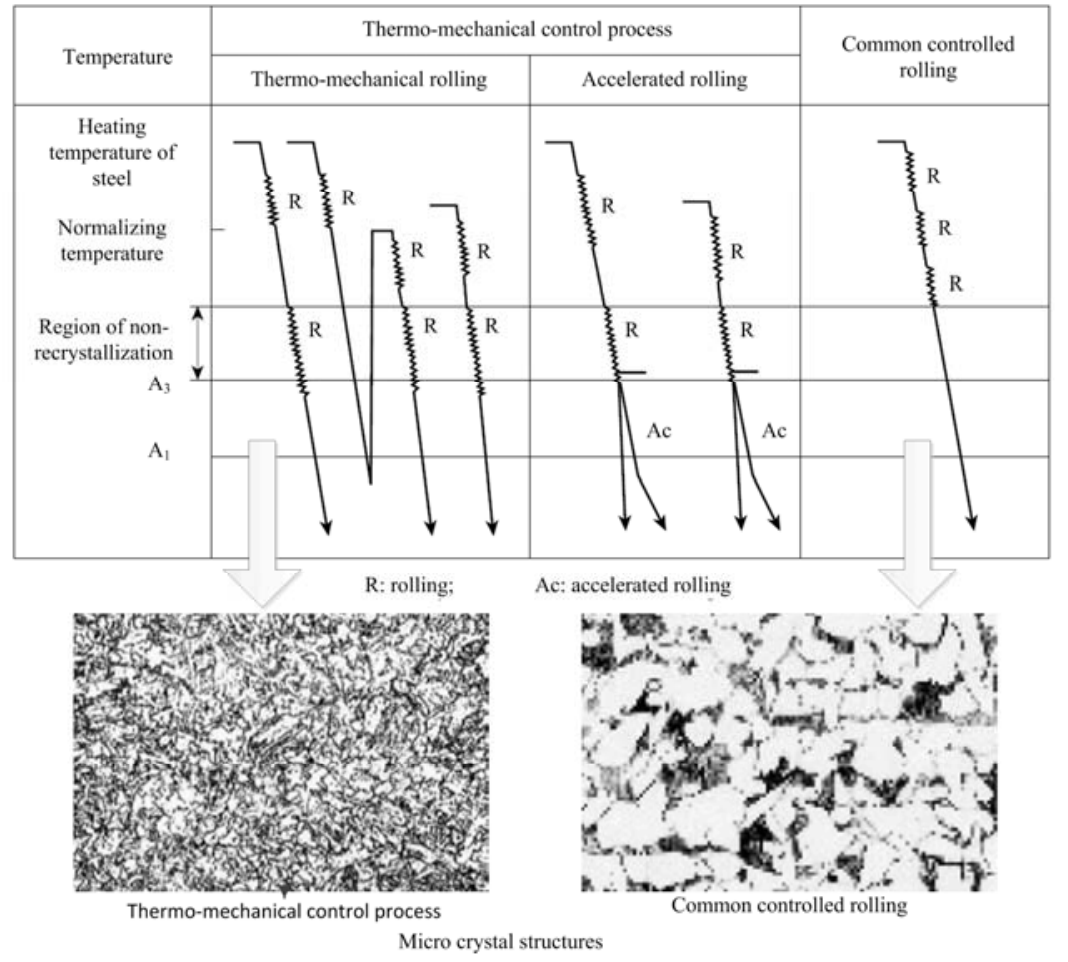

Figure 11. Thermo-mechanical Control Process for Plate Rolling (JIS G0201) 


\subsection{Strength Related HPS}

\subsubsection{Constant yield strength steels}

Yield strength of common steel generally decreases as plate thickness increases. For example, yield strength decreases when plate thickness is over $40 \mathrm{~mm}$ for most Japanese structural steels. A new series of constant yield strength steels listed in Table 3 for plate thickness within $40-100 \mathrm{~mm}$ are developed. Yield strength versus plate thickness curve of a constant yield strength steel, SM520-H [35], is compared with a common steel, SM520, in Figure 12. The constant yield strength steels have the following two virtues:

(1) constant yield strength for various plate thickness makes design simpler;

(2) yield strength of a thick plate is increased, which can reduce self-weight and makes design more economical.

\subsubsection{High strength cables}

Suspension bridge and cable stayed bridge are two popular structural types for long span bridges. In recent decades, strength of the cables is increasing gradually as illustrated in Figure 13. The high strength cables have the following merits:

Table 3 Yield strength of constant yield strengths steel and common steels

\begin{tabular}{|c|c|c|c|c|c|}
\hline $\begin{array}{c}\text { Constant yield } \\
\text { strength steel }\end{array}$ & $\begin{array}{c}\text { Plate thickness } \\
(\mathrm{mm})\end{array}$ & $\begin{array}{c}\text { SM400C-H } \\
\text { SMA400CW-H }\end{array}$ & SM490C-H & $\begin{array}{c}\text { SM520C-H } \\
\text { SMA490CW-H }\end{array}$ & $\begin{array}{c}\text { SM570-H } \\
\text { SM570W-H }\end{array}$ \\
\cline { 2 - 6 } & $40<t \leq 100$ & 140 & 185 & 210 & 255 \\
\hline \multirow{4}{*}{ Common JIS steel } & $\begin{array}{c}\text { Plate thickness } \\
(\mathrm{mm})\end{array}$ & $\begin{array}{c}\text { SM400 } \\
\text { SMA400W }\end{array}$ & SM490 & $\begin{array}{c}\text { SM520 } \\
\text { SMA490W }\end{array}$ & $\begin{array}{c}\text { SM570 } \\
\text { SM570W }\end{array}$ \\
\cline { 2 - 6 } & $16<t \leq 40$ & 140 & 185 & 210 & 255 \\
\cline { 2 - 6 } & $40<t \leq 75$ & 125 & 175 & 195 & 245 \\
\cline { 2 - 6 } & $75<t \leq 100$ & 125 & 175 & 190 & 240 \\
\hline
\end{tabular}

(1) reduce self-weight of the slabs;

(2) reduce self-weight of other structural components;

(3) more feasibility in structural design;

(4) shorten construction period and reduce cost of a whole project.

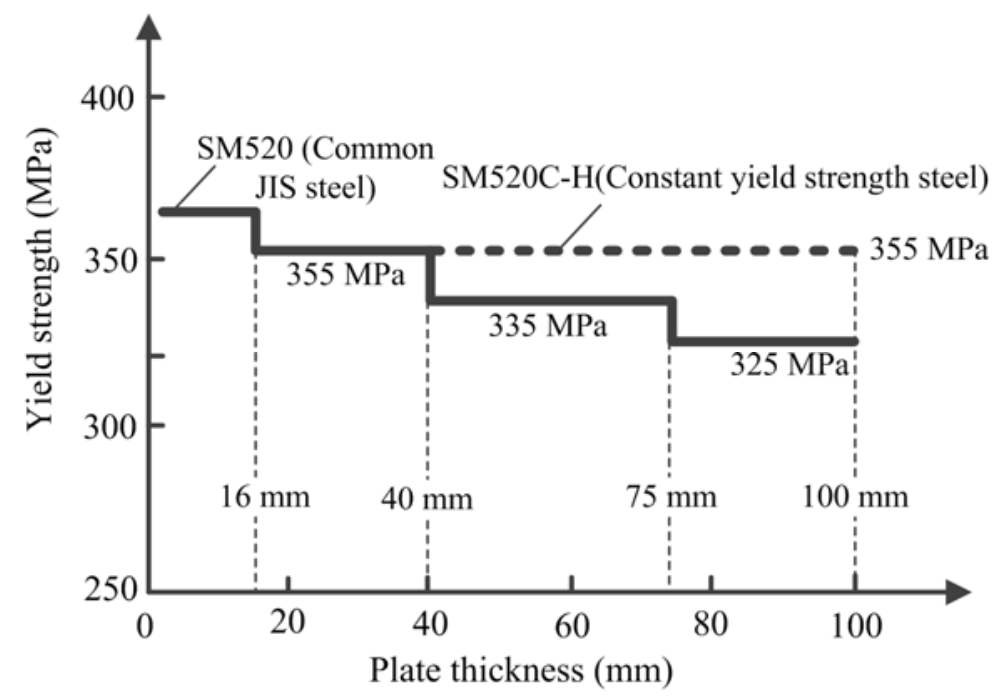

Figure 12. Yield Strength of Constant Strength Steel and Common Steel 


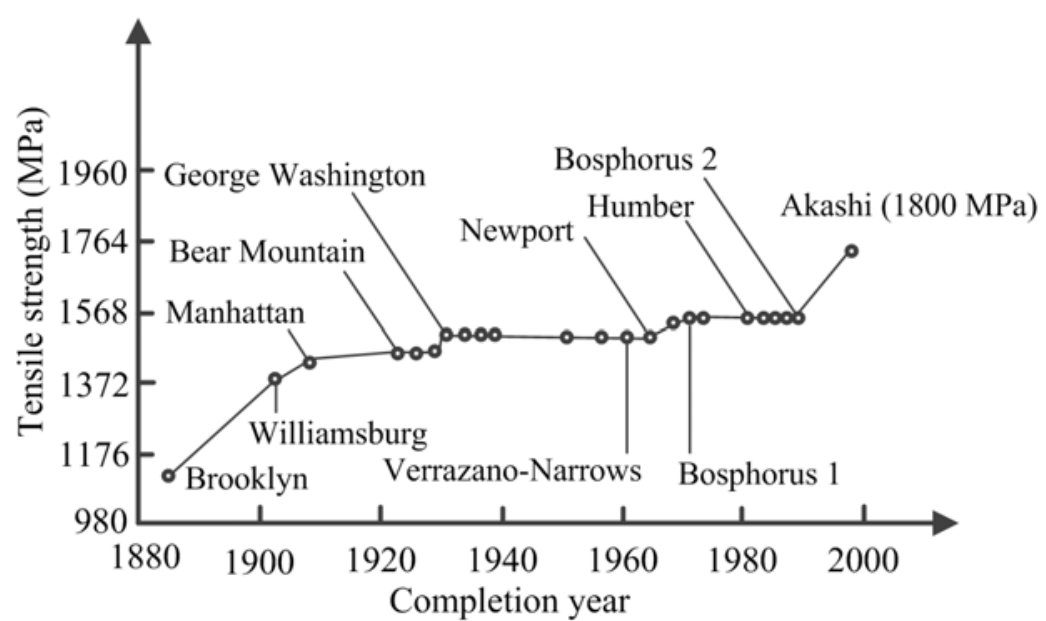

Figure 13. Development of High Strength Cables in Bridges

The strength of the two main cables employed in the Akashi bridge can reach $1800 \mathrm{MPa}$. It is reported that four main cables are required if $1600 \mathrm{MPa}$ cables are employed. Not only the self-weight of the cables, but also the self-weight of the main towers and the bridge deck is reduced by approximately $10 \%$. Meanwhile, the height of the main towers is also reduced from $320 \mathrm{~m}$ to $283 \mathrm{~m}$ for the increase of the cable strength.

\subsection{Toughness Related HPS}

Several properties are correlated with toughness of structural steel, such as cold forming properties and brittle fracture-resistant properties under low temperatures. It is known that cold forming will greatly reduce the ductility and toughness at regions with large bending curvatures (small bending radii). A material can fracture even during cold forming if the toughness is too low or the bending radius is too small. For common structural steel, a large bending radius of 15 times of the plate thickness is required. A series of high toughness steels are developed, and the bending radius can be reduced to 5 or 7 times of the plate thickness depending on the toughness of the material as shown in Figure 14 [35]. Besides, in cold areas such as Hokkaido in Japan, the temperature can decrease as low as $-40^{\circ} \mathrm{C}$, and high toughness steels are required to resist brittle fracture under the low temperature and meanwhile maintain ductility under a strong earthquake.

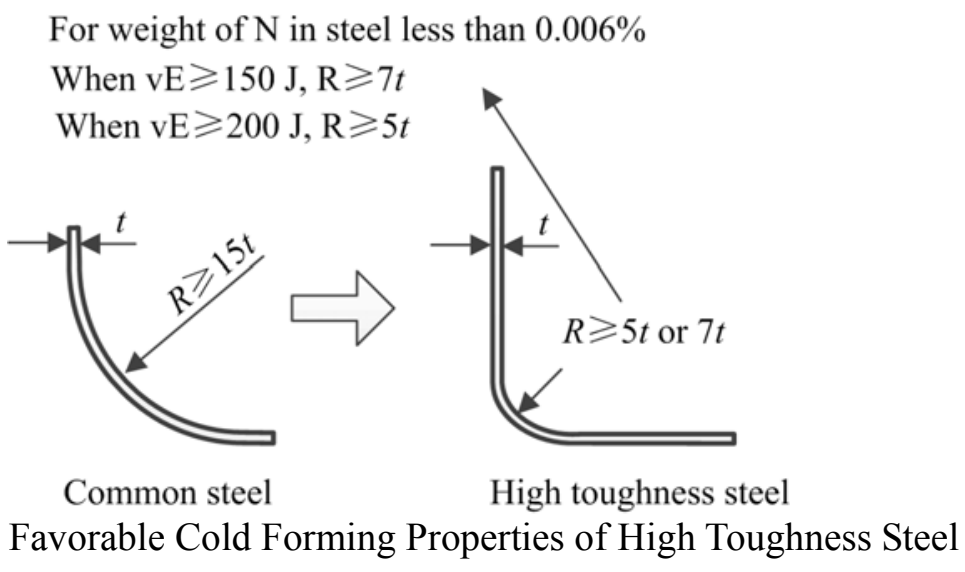

\subsection{Weldability Related HPS}

\subsubsection{Steel for high heat input welding}


Generally, tungsten inert gas (TIG) welding, metal inert gas (MIG) welding and electro-slag welding (ESW) are widely employed in bridge engineering. For common structural steel, a large amount of heat input will induce low toughness at the heat affected zone, and premature brittle fracture may occur. Therefore, strict control of the heat input is required in some design specifications, e.g., the maximum heat input for SM570 and SM490 are respective $70 \mathrm{~J}$ and $100 \mathrm{~J}$ in Japan [35]. On the other hand, welding using high heat input method such as the single pass welding process, ESW, is more productive compared with the multi-pass welding methods such as TIG and MIG, while the heat input is generally more than $370 \mathrm{~J}$, which is more than the specified value of the design code. A series of steel for high heat input welding is thus developed. Besides the high efficiency, the steel can also reduce the construction cost, especially for thick-walled steel plates. The welded connections using the steel also have high Charpy impact energy compared with common steel as illustrated in Figure 15. The micro-structure of the heat-affected zone using the steel for high heat input is much finer than those using conventional steel, and the weld thus has a superior fracture-resistant capacity. The micro-structure of a welded joint using the ESW process is shown in Figure 16 [36].

\subsubsection{Reduced preheating steel}

Weldability is commonly evaluated by the $P_{c m}$ in Japan, and a large value of $P_{c m}$ is correlated with poor weldability. Therefore, weldability becomes poor as the alloy content increases, and a thick-walled plate also has poor weldability. To avoid welding cracks, preheating is commonly required for thick-walled steel plates, especially in steel bridges where thick-walled plates are widely employed. However, it is not only inefficient but also difficult to carry out high temperature preheating in practice. A series of steel is developed to lower the required preheating temperature, and the steel has a relatively small value of $P_{c m}$ as shown in Figure 17, where the required preheating temperature can be controlled within $50{ }^{\circ} \mathrm{C}$.

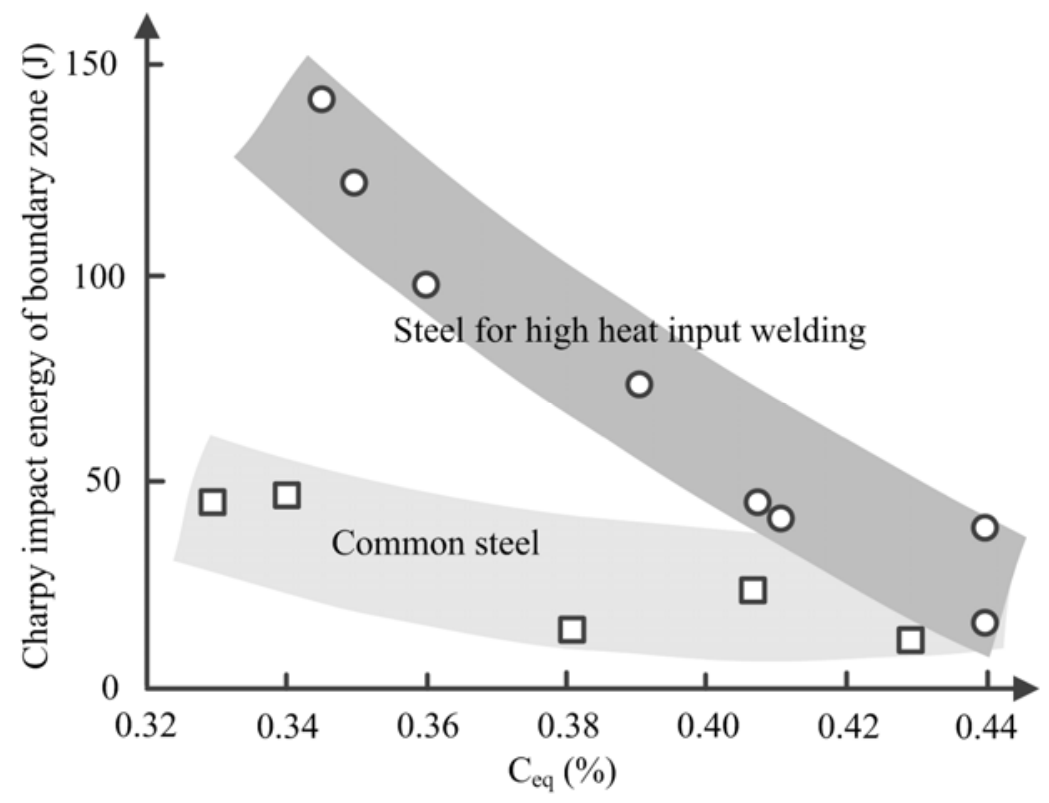

Figure 15. Comparison of toughness at Boundary Zone between Steel for High Heat Input Welding and Common Steel 

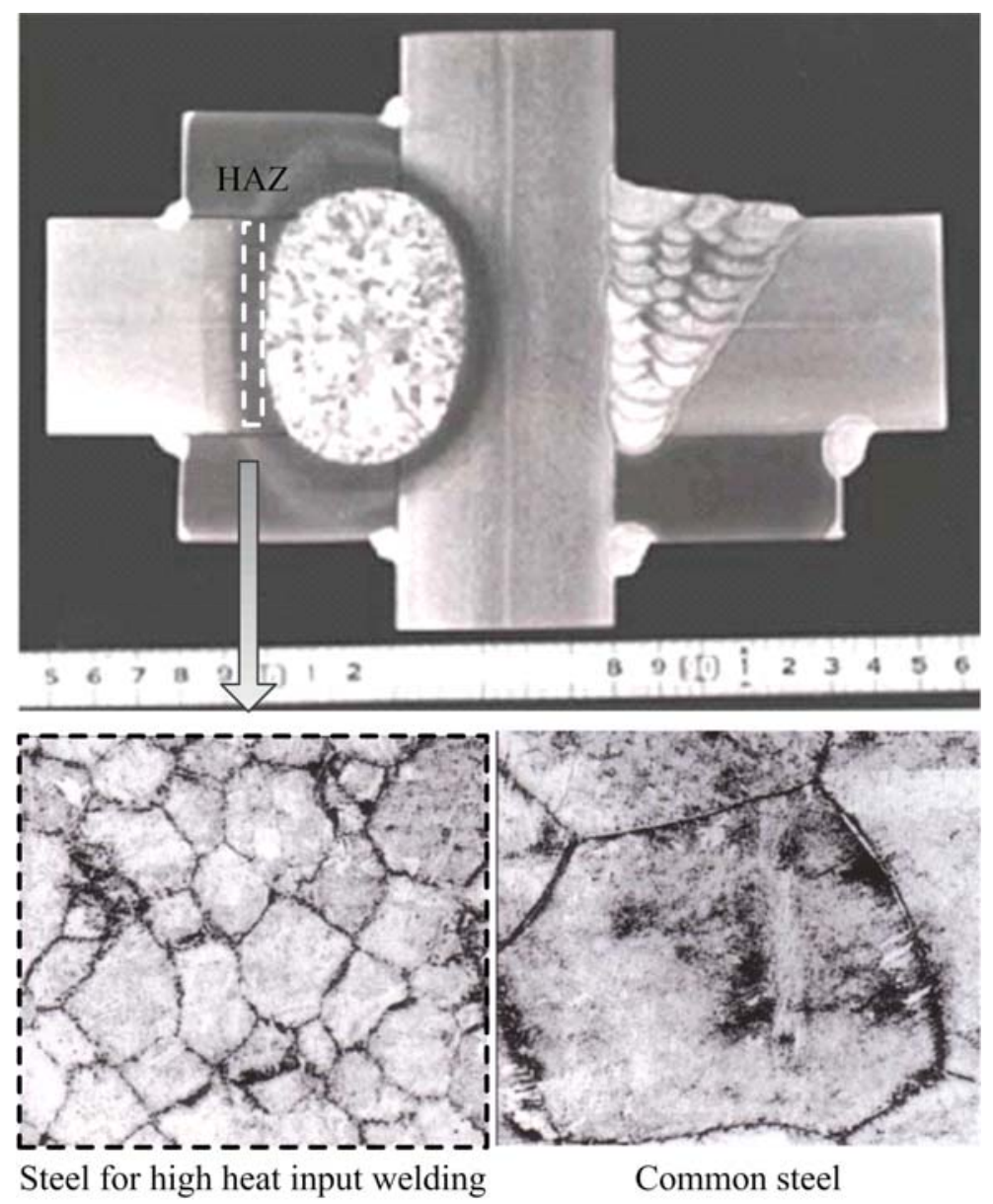

Figure 16. Application of Steel for High Heat Input Welding (adapted from [36])

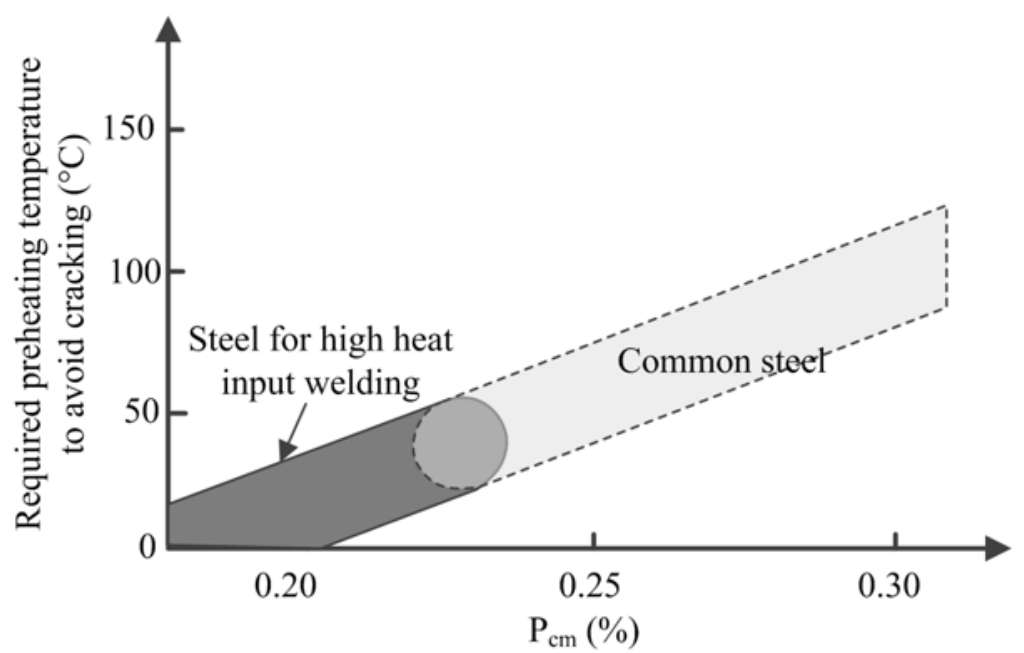

Figure 17 Preheating Requirements of Common Steel and Steel for High Heat Input Welding

\subsubsection{Lamellar tearing-resistant steel}

Impurities tend to accumulate at mid-thickness of a steel plate, and a thick-walled steel plate subjected to tensile stress along the thickness direction is susceptible to lamellar tearing as 
illustrated in Figure 18. The main affecting impurity for lamellar tearing is MnS. A series of lamellar tearing-resistant steel is developed by limiting the $\mathrm{S}$ content within $0.006 \%$ to $0.01 \%$, which corresponds to a reduction of area at fracture along the thickness direction within $15 \%$ to $35 \%$ [37]. The steel is applicable to welded thick-walled steel joints such as column flanges of beam-column connections.

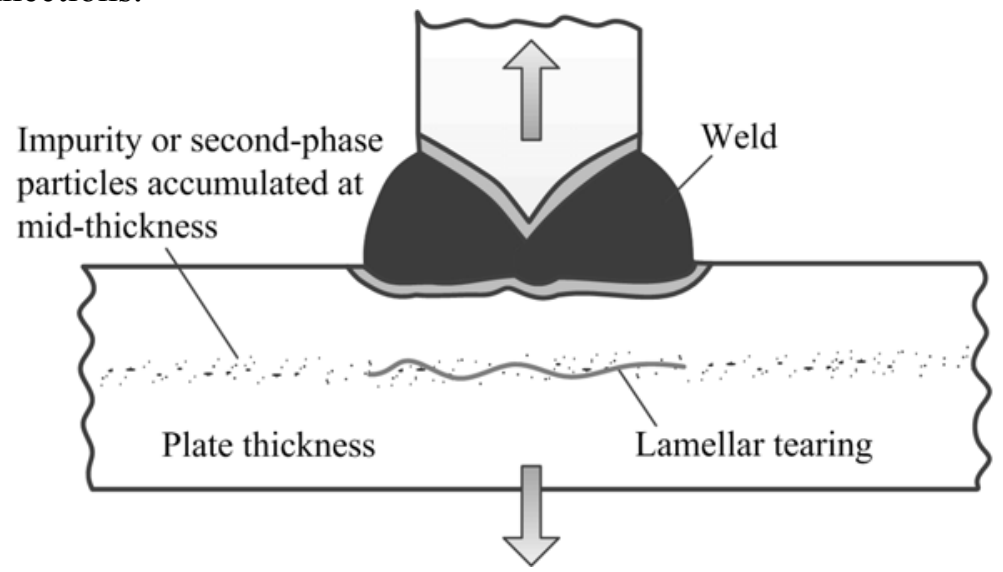

Figure 18. Illustration of Lamellar Tearing at Thick Steel Plates

\subsection{Connection Feasibility Related HPS}

Longitudinally profiled (LP) steel plates as shown in Figure 19 is another series of HPS developed for steel bridges. The LP steel plates have tapered sections along the thickness direction, which makes connections between two plates with different thickness simple. The stress conditions within the LP steel plates are also improved for the changing plate thickness. For these two virtues, less manufacturing work is required to connect two steel plates with different thickness, and the self-weight is also greatly reduced compared with common steel plates, which thus lower the construction fee.

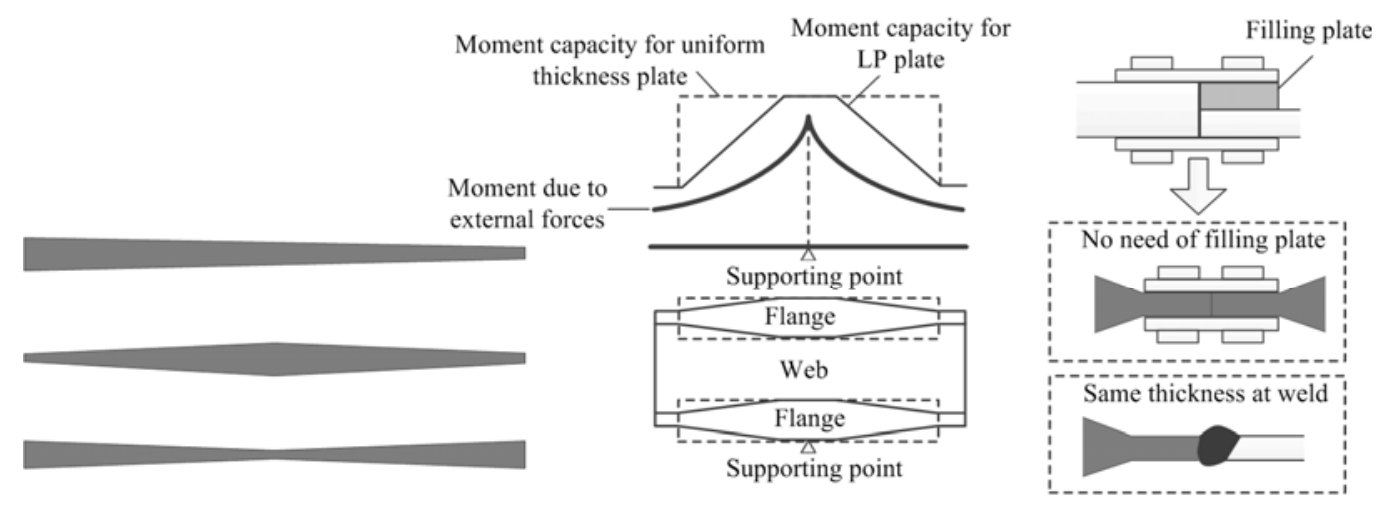

(a) Profile along longitudinal direction (b) More economical solutions at supporting point and joints Figure 19. Longitudinally Profiled Steel Plates and its Applications

\subsection{Durability Related HPS}

Weathering properties are very important for steel bridges, where commonly painting is required to protect the bridges from corrosion. Weathering steels are developed to enhance the corrosion-resistant properties of steel bridges, which have equivalent mechanical properties with common structural steel. These steels are commonly low alloy steels containing chemicals such as $\mathrm{Cu}, \mathrm{Cr}$ and $\mathrm{Ni}$ etc. The steels will form a fine rust layer in the presence of moisture and air as 
illustrated in Figure 20, which will prevent the inner material from further corrosion. For this mechanism, the rusting rate will be greatly slowed down compared with conventional steel. There are several benefits for application of the weathering steels, such as rapid construction, attractive appearance, minimal maintenance, and flexibility in future use. The steel bridges using weathering steels are more economical from the viewpoint of LCC.

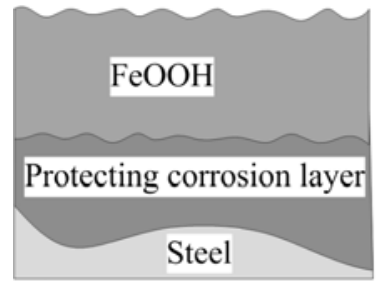

(a) Weathering steel

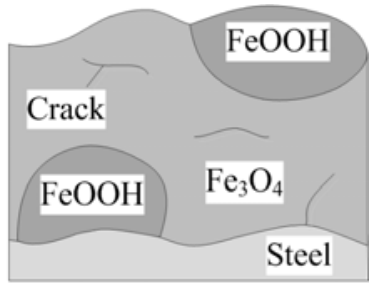

(b) Common steel

Figure 20. Illustration of Corrosion Mechanisms for Weathering Steel and Common Steel

\subsection{New HPSs for Steel Bridges}

A series of new HPSs termed BHS (bridge high performance steel) [38] have been developed to reduce the construction and maintenance costs of steel bridges. There are two steel grades, BHS500 and BHS700 (the current names are respective SBHS500 and SBHS700) [39], respectively with yield strengths no less than $500 \mathrm{MPa}$ and $700 \mathrm{MPa}$. The main characteristics of the BHS include:

(1) high yield strength;

(2) favorable construction feasibility such as large welding heat input as much as $10 \mathrm{~kJ} / \mathrm{mm}$ and reduced preheating temperature as listed in Table 4;

(3) high toughness;

(4) good weathering properties such as BHS500W and BHS700W, where "W" denotes weathering.

The BHS has been firstly employed in the construction of Tokyo Rinkai Chuo bridge in 2006, where most of the members in the truss bridge uses the new steel as shown in Figure 21 [40]. It is reported that the self-weight and manufacturing cost have been respectively reduced by approximately $3 \%$ and $12 \%$.

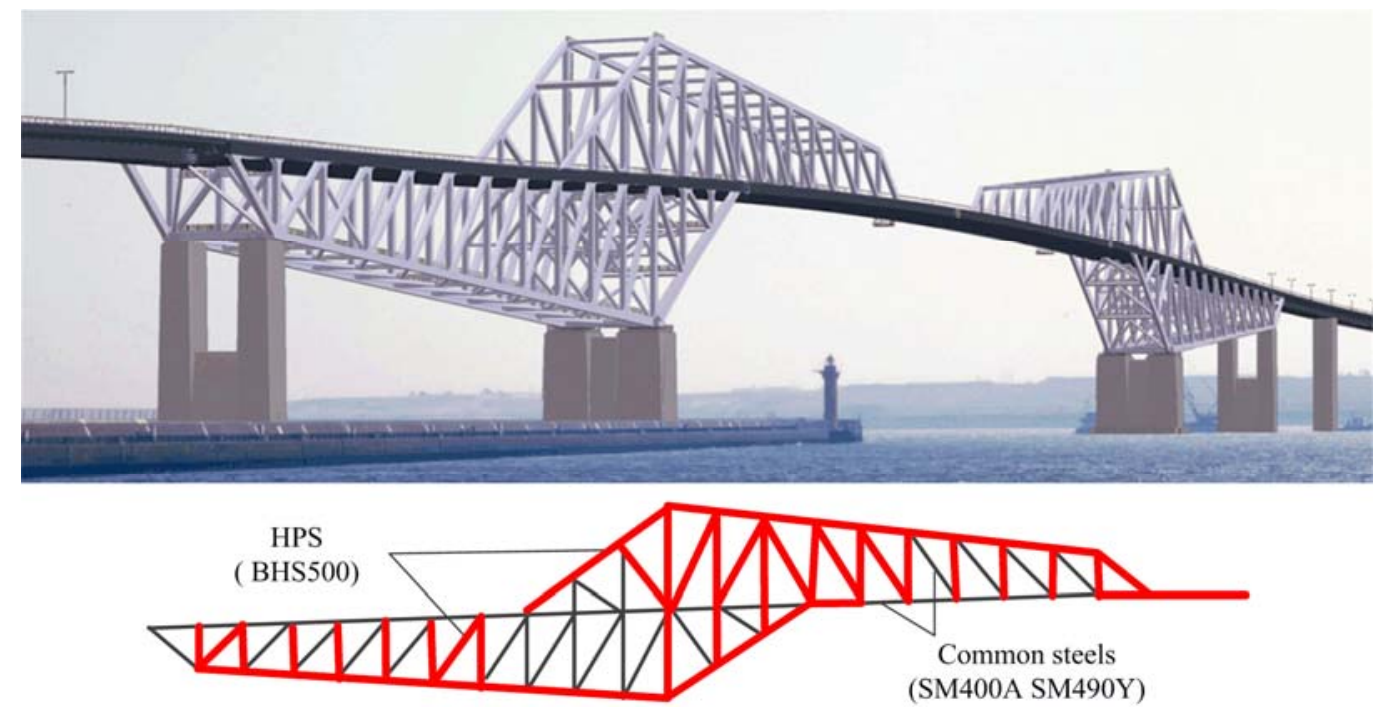

Figure 21. Application of High Performance Steel in Tokyo Rinkai Chuo Bridge (adapted from [40]) 
Table 4. Preheating Requirements for BHS Steels and Common Steels

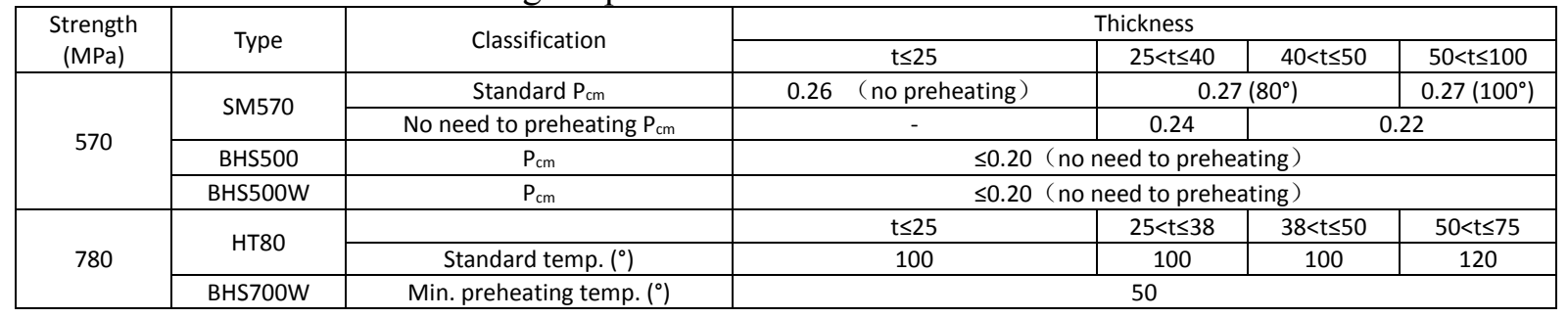

\section{SOCIAL AND ACADEMIC IMPACTS OF HPSS}

A number of high performance steels (HPSs) in Japan have been discussed in this study. These steels have great impacts on the whole society, such as:

(1) low construction and maintenance costs for steel structures;

(2) safer structures for the improved mechanical properties such as more stable yield strength and higher toughness;

(3) rapid construction speed;

(4) more feasibility for challenging structural proposals, e.g., high strength steel makes larger scaled structures possible.

There are also significant impacts on academic research of structural engineering, such as:

(1) new design methods for structures made of HPS;

(2) innovative structural systems;

(3) new energy dissipation components;

(4) new connecting technologies.

More research efforts are still required to promote the developments of these new technologies, and there is great potential for the application of HPS in future.

\section{ACKNOWLEDGEMENTS}

The study is supported in part by grants from the Advanced Research Center for Natural Disaster Risk Reduction, Meijo University, which supported by Ministry of Education, Culture, Sports, Science and Technology (MEXT), Japan. This study is also partially supported by National Nature Science Foundation of China (51508401) and the Fundamental Research Funds for the Central Universities.

\section{REFERENCES}

[1] Kitada, T., "Considerations on Recent Trends in, and Future Prospects of, Steel Bridge Construction in Japan", Journal of Constructional Steel Research, 2006, Vol. 62, No. 11, pp. 1192-1198.

[2] Bjorhovde, R., "Development and Use of High Performance Steel", Journal of Constructional Steel Research, 2004, Vol. 60, No. 3-5, pp. 393-400.

[3] Raoul, J. and Günther, H.-P., "Use and Application of Hgh-performance Steels for Steel Structures", IABSE, 2005.

[4] Bjorhovde, R., "Performance and Design Issues for High Strength Steel in Structures", Advances in Structural Engineering, 2010, Vol. 13, No. 3, pp. 403-411. 
[5] Miki, C., Homma, K. and Tominaga, T., "High Strength and High Performance Steels and Their Use in Bridge Structures", Journal of Constructional Steel Research, 2002, Vol. 58, No. 1, pp. 3-20.

[6] JSCE, "High Performance Steel for Seismic Design and High Ductility Structures". Japan Society of Civil Engineers, 2000.

[7] Ohata, M., "New Structural System Constructed Using New High-strength Steel Aiming for Non-damage during a Large Earthquake", Proceedings of 10th Korea-China-Japan Symposium on Structural Steel Construction, Seoul, South Korea, 2009, pp. 193-204.

[8] Mahin, S.A., "Lessons from Damage to Steel Buildings during the Northridge Earthquake", Engineering Structures, 1998, Vol. 20, No. 4-6, pp. 261-270.

[9] Bruneau, M., Wilson, J.C. and Tremblay, R., "Performance of Steel Bridges during the 1995 Hyogo-ken Nanbu (Kobe, Japan) Earthquake", Canadian Journal of Civil Engineering, 1996, Vol. 23, No. 3, pp. 678-713.

[10] AIJ, "Fracture in Steel Structures during a Severe Earthquake", Architectural Institute of Japan, Tokyo, 1995.

[11] Kuwamura, H., "Fracture of Steel during an Earthquake-State-of-the-Art in Japan", Engineering Structures, 1998, Vol. 20, No. 4-6, pp. 310-322.

[12] Kuwamura, H. and Yamamoto, K., "Ductile Crack as Trigger of Brittle Fracture in Steel", Journal of Structural Engineering (ASCE), 1997, Vol. 123, No. 6, pp. 729-735.

[13] Usami, T. and Ge, H.B., "A Performance-based Seismic Design Methodology for Steel Bridge Systems", Journal of Earthquake and Tsunami, 2009, Vol. 3, No. 03, pp. 175-193.

[14] Ge, H.B. and Kang, L., "A Damage Index-based Evaluation Method for Predicting the Ductile Crack Initiation in Steel Structures", Journal of Earthquake Engineering, 2012, Vol. 16, No. 5, pp. 623-643.

[15] Ge, H.B. and Kang, L., "Ductile Crack Initiation and Propagation in Steel Bridge Piers Subjected to Random Cyclic Loading", Engineering Structures, 2014, Vol. 59, pp. 809-820.

[16] Ge, H.B., Kang, L. and Tsumura, Y., "Extremely Low-cycle Fatigue Tests of Thick-walled Steel Bridge Piers", Journal of Bridge Engineering, 2013, Vol. 18, No. 9, pp. 858-870.

[17] Ge, H.B., Ohashi, M. and Tajima, R., "Experimental Study on Ductile Crack Initiation and Its Propagation in Steel Bridge Piers of Thick-walled Box Sections", J. Struct. Eng. JSCE A, 2007, Vol. 53, pp. 493-502.

[18] Kang, L. and Ge, H.B., "Predicting Ductile Crack Initiation of Steel Bridge Structures due to Extremely Low-cycle Fatigue using Local and Non-local Models", Journal of Earthquake Engineering, 2013, Vol. 17, No. 3, pp. 323-349.

[19] Chi, W., Deierlein, G. and Ingraffea, A., "Fracture Toughness Demands in Welded Beam-column Moment Connections", Journal of Structural Engineering (ASCE), 2000, Vol. 126, No. 1, pp. 88-97.

[20] Dexter, R. and Melendrez, M., "Through-thickness Properties of Column Flanges in Welded Moment Connections", Journal of Structural Engineering (ASCE), 2000, Vol. 126, No. 1, pp. 24-31.

[21] JISF, "Safety of Steel Structures Concerning Seismic Design, Tsunami Resistant Design and Steel", The Japan Iron and Steel Federation (JISF), Tokyo, 2013.

[22] El-Tawil, S., Mikesell, T. and Kunnath, S., "Effect of Local Details and Yield Ratio on Behavior of FR Steel Connections", Journal of Structural Engineering (ASCE), 2000, Vol. 126, No. 1, pp. 79-87.

[23] JIS. G3163, "Rolled Steels for Building Structure", Japanese Industrial Standards Committee, Tokyo, 2012.

[24] Nakamura, Y., Kambara, H., Nakai, M. and Maeda, Y., "Proposal for Design Method of Damage Free Structure Utilizing Super High Strength Steel: Part I: Study on Design Input Earthquakes of JMA Seismic Intensity 7". Summaries of Technical Papers of Annual Meeting Architectural Institute of Japan, Architectural Institute of Japan, 2007, pp. 201-202. 
[25] Aburakawa, M. and Nakai, M., "Design Method of New Building System (The Collaborative Project by Cabinet and Ministries)", Journal of the Japan Welding Society, 2009, Vol. 78, No. 7, pp. 605-611.

[26] Nakai, M., Tsuda, K., Mase, S., Narihara, H., Okayasu, T., Asai, H. and Suzuki, Y., "Performance Verification Through Full-scale Static Loading Tests for a Structural System using High Strength Steel", Journal of Structural and Construction Engineering (Transactions of AIJ), 2013, Vol. 78, No. 687, pp. 1007-1016.

[27] Kawabata, T., Arimochi, K., Hashida, T., Numata, T., Kohzu, I., Tada, M., Kuwahara, S. and Taga, K., "Investigation on Application of 1000N Class Ultra High Strength Steel for Buildings : Part 1. Evaluation of Properties of Base Plate", Summaries of Technical Papers of Annual Meeting Architectural Institute of Japan. A-1, Materials and construction, 2005, pp. 97-98.

[28] Sasaki, M., Ichinohe, Y., Nishio, M., Numata, T., Hashida, T., Kohzu, I., Tada, M., Kuwahara, S. and Taga, K., "Investigation on Application of $1000 \mathrm{~N}$ Class Ultra High Strength Steel for Buildings : Part 4. Outline of Tests and Performance of Developed Steel", Summaries of Technical Papers of Annual Meeting Architectural Institute of Japan. C-1, Structures III, Timber Structures Steel Structures Steel Reinforced Concrete Structures, 2007, pp. 889-890.

[29] Yasumura, M., Mukaide, S., Tada, M., Kohzu, I., Ichinohe, Y., Sasaki, M., Taga, K. and Numata, T., "Investigation on Application of 1000N Class Ultra High Strength Steel for Building: Part 8. Analytical Investigation on Local Buckling Properties of H-section Column", Summaries of Technical Papers of Annual Meeting Architectural Institute of Japan. C-1, Structures III, Timber Structures Steel Structures Steel Reinforced Concrete Structures, Vol. 2007, pp. 897-898.

[30] Murakami, Y., Sugimoto, M. and Fukuda, K., "Recent Trend of Structural Steel Development: Application of Ultra-high Strength Steel to Building Structures", Journal of Steel Structures \& Construction (JSSC), 2014, No. 17, pp. 42-46.

[31] Suzui, Y., Niwa, H., Fuchita, Y., Tokinoya, H., Yamanaka, M. and Endo, F., "Ultra High Strength Concrete-filled Steel Tube Column", Report of Obayashi Corporation Technical Research Institute, Tokyo, 2010.

[32] JISF, "Amagasaki Research and Development Center-Employing 1000 N-grade Steel", Steel Construction Today \& Tomorrow, 2010, No. 38, pp. 2.

[33] Steel Club. "Fireproofing Structural Steel for Building Structures", The Japan Iron and Steel Federation, Tokyo, 2000.

[34] JIS. G0201, "Glossary of Terms used in Iron and Steel (Heat Treatment)", Japanese Industrial Standards Committee, Tokyo, 2000.

[35] JRA. "Specification for Highway Bridges", Japan Road Association, Tokyo, 2012.

[36] Fujisawa, K., "State of Art for High Performance Steel", Steel Construction Symposia, Tokyo, 2013.

[37] JIS. G3199, "Specification for Through-thickness Characteristics of Steel Plate, Wide Flat and Sections", Japanese Industrial Standards Committee, Tokyo, 2009.

[38] Miki, C., Ichikawa, A., Kusunoki, T. and Kawabata, F., "Proposal of New High Performance Steels for Bridges (BHS500, BHS700)", Journal of Structural Mechanics and Earthquake Engineering, Japan Society of Civil Engineers, 2003, No. 738, pp. 1-10.

[39] JIS. G3140, "Higher Yield Strength Steel Plates for Bridges", Japanese Industrial Standards Committee, Tokyo, 2011.

[40] Wada, K., Tanaka, K. and Kodama, Y., "Project of Tokyo-Port Seaside Bridge", Kawada Technical Report, Tokyo, 2009. 